papers. Dr. Hoare is head of the Tinplate Section of the Tin Research Institute, having originally begun his career as a metallurgist with the Talbot Motors Company, and Mr. Lewis is development manager at the Institute.

\section{United States Research Fellowships to British Scientific Workers}

Research fellowships tenable in American institutions under a technical assistance programme sponsored by the United States Foreign Operations Administration have been awarded by the National Academy of Sciences, Washington, on the nomination of the Royal Society, London, to five British scientific workers as follows: G. V. Chester, scientific officer, Radar Research Establishment (Ministry of Supply), to work at Yale University, under Prof. J. G. Kirkwood, in the field of statistical mechanics and, in particular, on the molecular theory of fluids; Dr. R. A. Gibbons, research assistant, Department of Biochemistry, Lister Institute of Preventive Medicine, London, to work at the Ohio State University, Columbus, under Prof. M. L. Wolfrom, on problems in connexion with the human blood-group substances ; C. G. James, research student in the Department of Physical Chemistry, Cambridge, to work in the University of California, Berkeley, under Prof. Leo Brewer, in the general field of high-temperature thermochemistry and flame equilibria; I. M. Mills, research student in the Department of Chemistry, Oxford, to carry out research in infra-red spectra at the University of Minnesota, under Prof. Bryce Crawford, jun.; Dr. G. L. Squires, a senior research Fellow at the Atomic Energy Research Establishment, Harwell, to work under Dr. Robert Oppenheimer in the Institute for Advanced Study, Princeton, New Jersey, for about three months and then under Drs. John and Leona Marshall in the Institute for Nuclear Studies of the University of Chicago, on experiments in meson physics. This brings to sixteen the number of awards to candidates from the United Kingdom in a programme which, instituted in 1953, is intended to enable some hundred and fifty outstanding young scientific workers from fourteen Western European countries to carry out advanced study for up to two years at American universities and research institutions; part of the time mayr be spent in American industrial or applied science research laboratories. The grants are worth about 3,300 dollars (approximately $£ 1,180$ ) a year plus travel expenses.

\section{The Nature Conservancy: Annual Report}

According to the report of the Nature Conservancy for the year ended September 30, 1954 (see p. 1159 of this issue), by the end of that year the Conservancy had notified under Section 23 of the National Parks and Access to the Countryside Act, $1949,1,098$ sites of special scientific interest in England (coming under sixty-eight planning authorities) and 148 in Wales (coming under thirteen authorities). Progress in Scotland was slower; but by the end of the year seventy-seven sites had been notified to twelve authorities. By the end of the year 528 geological sites out of the 634 proposed for conservation had been inspected, and nearly two hundred photographs of such sites were taken. Only at the beginning of the year did it become possible to trace and write on a large scale to the owners and occupiers of such sites, which vary widely both in size and in the character of their scientific interest.
Considerably less than half the owners notified have replied, the great majority promising co-operation; only a small minority has taken exception. In future, where tenants and proprietors can be traced, they will be consulted before further areas are notified to local planning authorities ; but it is emphasized that notification is merely a means of informing authorities, owners and occupiers of the fact that they have something of outstanding natural and scientific interest on their land, and the Conservancy has been encouraged by the readiness of many owners to welcome scientists and to see that the scientific interest is preserved.

The report also deals at some length with the new statutory responsibilities of the Conservancy under the Protection of Birds Act, 1954, which came into force on December 1. Under Section 10 of that Act, the Conservancy is responsible for issuing licences in connexion with interference with bird life for scientific or educational purposes for work sponsored by the Conservancy ; and it is also one of the bodies empowered to nominate an authorized person for pest control and other specified purposes. Despite certain difficulties, the Nature Conservancy believes that it will be possible to reach agreement on a broad policy in regard to wild-fowl refuges, which will combine the requirements of nature conservation with those of sportsmen, particularly wild-fowlers.

\section{Viruses and the Control of Insect Pests}

OUTBREAKs of insect pests are often brought to an end by outbreaks of infectious disease, and many attempts have been made to control harmful insects by spreading disease among them. In the past the results have been disappointing: the infective organisms have soon lost their virulence. But in recent years some strikingly effective epidemics of disease among insect pests have led to a renewed interest in the method. In 1945 the population of the spruce sawfly in eastern Canada, after reaching alarming proportions, just melted away before a virus disease. This episode served to focus attention on the insect viruses, and that has led in turn to the practical use of introduced virus diseases for insect control, on one hand, and a great increase in our knowledge of these diseases, on the other. In the November number of Discovery, Dr. Kenneth M. Smith, of the Agricultural Research Council's Virus Research Unit, at Cambridge, contributes an interesting article which outlines both the fundamental knowledge of insect viruses that has recently been obtained and some of the practical achievements. Thus the alfalfa butterfly in California has been effectively controlled by spraying the crop with stored polyhedra obtained from diseased caterpillars, and the pine sawfly in Canada has been controlled by a virus of polyhedral type procured from Sweden. A very interesting discovery is that some virus diseases are not highly specific, but can attack a number of different species of Lepidoptera; sometimes the virulence of the infection can be increased by mixing two viruses. In general, the persistent nature of the viruses and the fact that they do not affect the natural enemies of the pests make them a promising alternative to insecticides.

\section{Third International Congress of Biochemistry, Brussels}

THE Third Tnternational Congress of Biochemistry will be held in Brussels during August 1-6, 1955, 